\title{
Postnatal Changes in Oxygen Transport of Term, Premature, and Sick Infants: The Role of Red Gell 2,3-Diphosphoglycerate and Adult Hemoglobin
}

\author{
Maria Delivoria-Papadopoulos ${ }^{[45}$, Nevenka P. Roncevic, and Frank A. Oski \\ Department of Physiology, University of Pennsylvania School of Medicine, and the Departments of Pediatrics, Hospital of the \\ University of Pennsylvania and the Children's Hospital of Philadelphia, Philadelphia, Pennsylvania, USA
}

\begin{abstract}
Extract
In view of previous studies which did not show a precise relation between the percentage fetal hemoglobin and the position of the oxygen hemoglobin equilibrium curve, this problem was reexamined taking into account both the concentration of fetal hemoglobin and the 2,3-diphosphoglycerate (2,3-DPG) content of the cell.

Forty-eight normal infants weighing $2500 \mathrm{~g}$ or more at birth were studied on days 1 and 5 of life and then at 3 and $6-9$ weeks, and at 3-4,5-6, and 8-11 months of age. Fifty-six infants ranging in birth weight from 900 to $2420 . \mathrm{g}$ were studied during the first 8 days of life and then at 2- to 3-week intervals until approximately 16 weeks of life. Twelve premature infants who were ill with the respiratory distress syndrome were also stúdied.

Laboratory procedures consisted of measurement of total hemoglobin, fetal hemoglobin, red cell 2,3-DPG, and oxygen equilibrium curves.

The "functioning DPG fraction" in millimicromoles per milliliter red blood cells (RBC) was obtained by multiplication of the total red cell DPG content (millimicromoles per milliliter RBC) by the percentage of adult hemoglobin.

These studies confirm previous observations that the term infant begins life with blood that has an increased affinity for oxygen. During the first few months of life the oxygen-hemoglobin equilibrium curve gradually shifts to the right and between 4 and 6 months of age becomes similar to that observed in the normal adult.

The change in $P_{50}$ in these infants correlated neither with the change in red cell DPG content alone nor with the decline in fetal hemoglobin alone. Instead, the progressive decrease in oxygen affinity during the first 6 months of life correlated significantly $(r=0.876, P<0.001)$ with the functioning DPG fraction. The term "functioning DPG fraction" is suggested to reflect the fact that both the DPG concentration and the adult hemoglobin concentration within the cell, with which the DPG interacts, are necessary factors in determining the position of the oxygen equilibrium curve.

Infants with respiratory distress appear to have $P_{50} s$ that are lower than those of healthy infants of similar gestational age and birth weight. This appears to be primarily a result of a decrease in red cell DPG concentration. It is this type of infant who may benefit from exchange transfusion with fresh adult blood.
\end{abstract}




\begin{abstract}
Speculation
It would appear that the fetal red cell with its fetal hemoglobin that is less able to interact with DPG and decrease its affinity for oxygen is well suited for the fetus in its intrauterine environment. The same hemoglobin, however, appears poorly suited to meet the demands of extrauterine stress because of an inability to respond to hypoxia by significantly increasing oxygen unloading capacity. In situations of hypoxic stress the newborn infant might fare better if his blood were replaced with the fresh blood of an adult.
\end{abstract}

\section{Introduction}

In 1930 Anselmino and Hoffman [2] first observed that the oxygen affinity of human fetal blood was greater than that of maternal blood. In 1931 Haselhorst and Stromberger [20] and in 1933 Eastman and associates [17] also demonstrated that the oxygen tension at which hemoglobin is half-saturated, $\mathrm{P}_{50}$, was approximately $6 \mathrm{~mm} \mathrm{Hg}$ lower in cord blood than in maternal blood.

In 1953 Allen, Wyman, and Smith [1] showed that, although the intact fetal cell possessed a higher affinity for oxygen than did the red cells of normal adults, when adult and fetal hemoglobin solutions were dialyzed against the same surrounding solution the resulting oxygen affinities were identical. They suggested, therefore, that the reported differences in oxygen equilibria may result from differences in the environment of the hemoglobin molecule rather than from intrinsic properties of the molecule itself. These findings were confirmed and extended in 1962 by Schruefer et al. [32] and most recently by Bauer et al. [7].

Studies of the properties of the intracellular environment and of the membrane have failed to provide an explanation for the differences in oxygen affinity of the two types of cells $[12,22]$. In 1967 Benesch and Benesch [9] and Chanutin and Curnish [11] demonstrated that the affinity of a solution of adult hemogiobin for oxygen may be decreased by its interaction with organic phosphates. The two principal organic phosphates of the human erythrocyte, 2,3-DPG, and adenosine triphosphate (ATP) combine reversibly with deoxyhemoglobin and shift the oxygen-hemoglobin equilibrium curve to the right. Since 2,3-DPG comprises approximately $60 \%$ of the organic phosphate of the human red cell, it is quantitatively the most important in this regard. Subsequent studies in older children and adults have shown a precise relation between red cell 2,3-DPG content and the position of the oxygen-hemoglobin equilibrium curve $[14,18,24$, $26,27]$.
Studies employing fetal hemoglobin have failed to demonstrate this interaction with 2,3-DPG. Both 2,3DPG and ATP had little effect on altering the oxygen affinity of fetal hemoglobin while their effect on the oxygen affinity of adult hemoglobin was profound $[6,15,30,37]$.

In view of previous studies which did not show a precise relation between the percentage fetal hemoglobin and the position of the oxygen-hemoglobin equilibrium curve $[4,8]$ this problem was reexamined taking into account both the concentration of fetal hemoglobin and the 2,3-DPG content of the cell.

Premature and term infants were studied sequentially, and evidence will be presented to demonstrate that the oxygen affinity of hemoglobin, as reflected by the $P_{50}$, is determined neither by the concentration of fetal hemoglobin nor by that of 2,3-DPG alone but by the interaction of 2,3-DPG with the adult hemoglobin present in the red cells of the developing infants. In addition, the consequences of these changes on oxygen delivery and its alterations in neonatal disease will be described.

\section{Materials and Methods}

\section{Subjects}

Term infants. Forty-eight normal infants weighing 2500 or more at birth were studied on days 1 and 5 of life and then at 3 and 6-9 weeks, 3-4, 5-6, and 8-11 months of age. Some randomly selected healthy infants were also studied at periods ranging from 3 to 11 months of age.

Premature infants. Fifty-six infants ranging in birth weight from 900 to $2420 \mathrm{~g}$ were studied during the first 8 days of life and then at 2- to 3-week intervals until approximately 16 weeks of life.

Sick infants. This group was comprised of 12 premature infants who were ill with the respiratory distress syndrome. In four infants exchange transfusions or simple blood transfusions were performed. 
Controls. Twenty healthy, nonsmoking adults served as normal controls.

\section{Laboratory Procedures}

Six to ten milliliters blood were obtained from each infant anaerobically in well heparinized syringes [41]. The blood was kept chilled in wet ice until the time of analysis.

Total hemoglobin concentration, hematocrit, and reticulocyte counts were performed by standard hematological techniques. The mean corpuscular hemoglobin concentration (MCHC) was obtained from the ratio of hemoglobin to hematocrit.

Fetal hemoglobin was determined by alkali denaturation [35]. Red cell 2,3-DPG was determined by the method of Krimsky [23] as modified by Schröter and Heyden [31] employing the extraction procedure described by Beutler et al. [10] for 0.1-ml samples of blood.

The oxygen equilibrium curves were obtained by directly measuring the oxygen tension, $\mathrm{pH}$, and oxygen saturation following equilibration of whole blood (at a constant carbon dioxide tension) at varying oxygen contents. At least three points were obtained for each curve with oxygen saturation ranging from 30 to $60 \%$ at a constant temperature of $37^{\circ}$. The $\mathrm{P}_{50}$ was then obtained from the regression line drawn through the data points on the steep part of the oxygen equilibrium curve [14]. The $\mathrm{PO}_{2}$ and $\mathrm{PCO}_{2}$ were measured with the appropriate electrodes at $37^{\circ}$ [34] and the $\mathrm{pH}$ with a radiometer glass microelectrode while the oxygen saturation was measured directly by a spectropho- tometric technique on lysed whole blood [28]. The n values were calculated using Hill's expression $\log \left[\mathrm{So}_{2} /\right.$ $\left.100-\mathrm{So}_{2}\right]=\operatorname{nlog} \mathrm{Po}_{2}+\log \mathrm{K}$. To compare the affinity of the hemoglobin for oxygen in different clinical situations all $\mathrm{P}_{50} \mathrm{~s}$ were corrected to $\mathrm{pH} 7.40$ using the Bohr factor of -0.485 [33].

Oxygen capacity in milliliters of oxygen per $100 \mathrm{ml}$ of blood was calculated by multiplication of the hemoglobin concentration in grams per $100 \mathrm{ml}$ by 1.39 [38]. Where the blood sample was sufficient, oxygen capacity was measured directly by the Van Slyke technique.

The unloading capacity in milliliters of oxygen per $100 \mathrm{ml}$ of blood was calculated from the oxygen equilibrium curve, with oxygen content instead of oxygen saturation on the ordinate. It represents the amount of oxygen that can be extracted from the blood for a given difference in $\mathrm{Po}_{2}$. As "arterial" point we chose the $\mathrm{PO}_{2}$ which gave $95 \%$ saturation; the "venous" $\mathrm{Po}_{2}$ was assumed to be $40 \mathrm{~mm} \mathrm{Hg}$.

The "functioning DPG fraction" in millimicromoles per milliliter RBC was obtained by multiplication of the total red cell DPG content (millimicromoles per milliliter RBC) by the percentage of adult hemoglobin. The whole blood buffer base in milliequivalents per liter was calculated by the Henderson-Hasselbach equation and corrected for the measured hematocrit [36].

\section{RESULTS}

\section{Normal Term Infants}

The results of the studies of 48 normal term infants are presented in Table $\mathrm{I}$. The mean $\mathrm{P}_{50}$ on the first

Table $I$. Oxygen transport in term infants

\begin{tabular}{|c|c|c|c|c|c|c|c|c|c|c|}
\hline $\begin{array}{c}\text { No. } \\
\text { of } \\
\text { infants }\end{array}$ & Age & $\begin{array}{l}\text { Total Hb, } \\
\text { g/100 ml } \\
\text { blood }\end{array}$ & $\underset{\%}{\text { Hct, }}$ & $\underset{\%}{\mathrm{MCHC}}$ & $\begin{array}{c}\mathrm{O}_{2} \text { capacity } \\
\text { ml/100 ml } \\
\text { blood }\end{array}$ & $\begin{array}{c}\mathrm{P}_{50} \text { at } \mathrm{pH} \\
7.40, \\
\mathrm{~mm} \mathrm{Hg}\end{array}$ & $\begin{array}{c}\text { 2,3-DPG, } \\
\mathrm{m} \mu \mathrm{moles} / \mathrm{ml} \\
\mathrm{RBC}\end{array}$ & $\begin{array}{l}\text { Fetal } \\
\mathrm{Hb}, \% \\
\text { of total }\end{array}$ & $\begin{array}{c}\text { FFDPG, } \\
\mathrm{m} \mu \mathrm{moles} / \mathrm{ml} \\
\mathrm{RBC}\end{array}$ & $\begin{array}{c}\text { Reticulocyte } \\
\text { count, } \\
\%\end{array}$ \\
\hline \multirow[t]{2}{*}{19} & 1 day & 17.8 & 52.7 & 34.2 & 24.7 & 19.4 & 5433 & 77.0 & 1246 & 4.7 \\
\hline & & $\pm 2.0^{2}$ & \pm 7.1 & \pm 1.9 & \pm 2.8 & \pm 1.8 & \pm 1041 & \pm 7.3 & \pm 570 & \pm 1.74 \\
\hline \multirow[t]{2}{*}{18} & 5 days & 16.2 & 46.9 & 34.1 & 22.6 & 20.6 & 6580 & 76.8 & 1516 & 2.15 \\
\hline & & \pm 1.2 & \pm 6.0 & \pm 0.8 & \pm 2.2 & \pm 1.7 & \pm 996 & \pm 5.8 & \pm 495 & \pm 1.64 \\
\hline \multirow[t]{2}{*}{14} & 3 weeks & 12.0 & 33.5 & 35.9 & 16.7 & 22.7 & 5378 & 70.0 & 1614 & 0.88 \\
\hline & & \pm 1.3 & \pm 4.3 & \pm 1.2 & \pm 1.9 & \pm 1.0 & \pm 732 & \pm 7.33 & \pm 252 & \pm 0.71 \\
\hline \multirow[t]{2}{*}{10} & $6-9$ weeks & 10.5 & 30.2 & 34.9 & 14.7 & 24.4 & 5560 & 52.1 & 2670 & 1.63 \\
\hline & & \pm 1.2 & \pm 3.9 & \pm 0.6 & \pm 1.6 & \pm 1.4 & \pm 747 & \pm 11.0 & \pm 550 & \pm 0.65 \\
\hline \multirow[t]{2}{*}{14} & 3-4 months & 10.2 & 30.3 & 33.8 & 14.3 & 26.5 & 5819 & 23.2 & 4470 & 1.36 \\
\hline & & \pm 0.8 & \pm 2.4 & \pm 1.7 & \pm 1.2 & \pm 2.0 & \pm 1240 & \pm 16.0 & \pm 1380 & \pm 0.45 \\
\hline \multirow[t]{2}{*}{8} & 6 months & 11.3 & 34.0 & 33.4 & 14.7 & 27.8 & 5086 & 4.7 & 4840 & 1.42 \\
\hline & & \pm 0.9 & \pm 3.6 & \pm 0.7 & \pm 0.6 & \pm 1.0 & \pm 1570 & \pm 2.2 & \pm 1500 & \pm 1.15 \\
\hline \multirow[t]{2}{*}{8} & 8-11 months & 11.4 & 34.8 & 32.8 & 15.9 & 30.3 & 7381 & 1.6 & 7260 & 0.82 \\
\hline & & \pm 0.6 & \pm 1.9 & \pm 0.9 & \pm 0.8 & \pm 0.7 & \pm 485 & \pm 1.0 & \pm 544 & \pm 0.27 \\
\hline
\end{tabular}

1 Functioning fraction of 2,3-diphosphoglycerate.

${ }^{2}$ All values are given as mean $\pm 1 \mathrm{SD}$. 


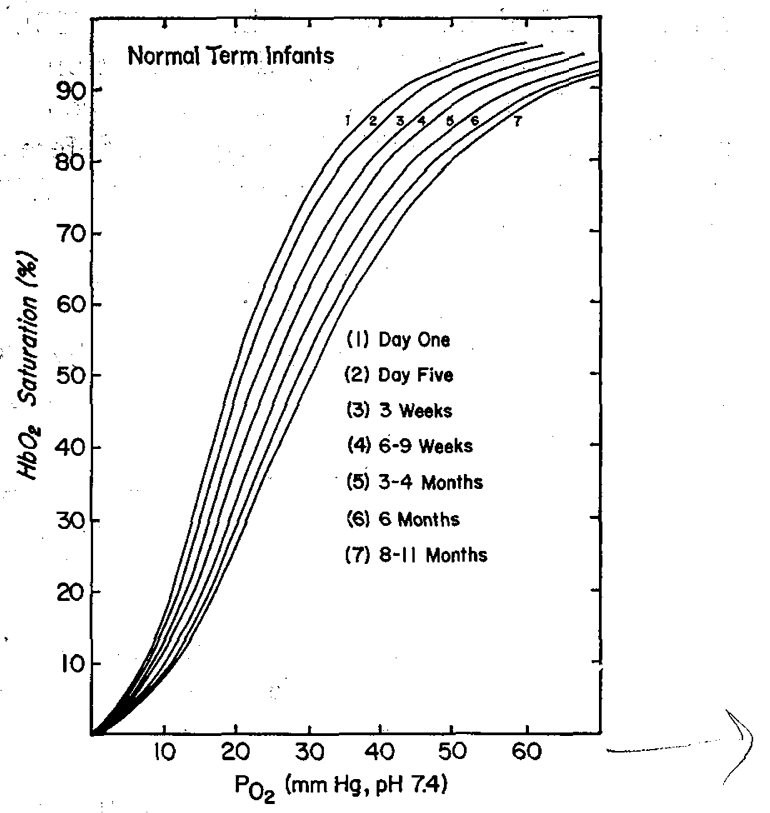

Fig. 1. Oxygen equilibrium curves of blood from term infants at different postnatal ages; each curve represents the mean value of the infants studied in each age group.

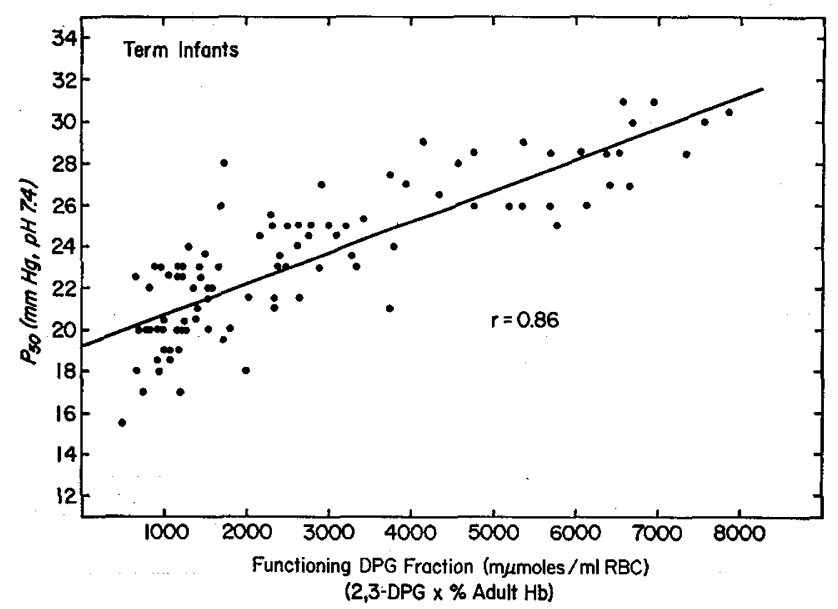

Fig. 2. The $\mathrm{P}_{50}$ and functioning DPG fraction of all term infants at different postnatal ages.

day of life was $19.4 \pm 1.8 \mathrm{~mm} \mathrm{Hg}$ as contrasted with a value of $27.0 \pm 1.1 \mathrm{~mm} \mathrm{Hg}$ for the normal adults. In these infants the $P_{50}$ rose significantly during the first 5 days of life to $20.6 \pm 1.7 \mathrm{~mm} \mathrm{Hg}(P<0.05)$. From day 5 the $P_{50}$ gradually continued to increase and reached normal adult values by months 4-6 of life (Fig. 1). The red cell DPG on day 1 averaged $5433 \pm 1041$ $\mathrm{m} \mu$ moles/ml RBC and thus did not differ significantly from that of the normal adults (5114 $\pm 418 \mathrm{~m} \mu$ moles/ $\mathrm{ml} \mathrm{RBC})$. By day 5 the DPG had increased to $6580 \pm$
$996 \mathrm{~m}_{\mu}$ moles $/ \mathrm{ml} \mathrm{RBC}$ and then gradually declined. By 8-11 months of age the $P_{50}$ in these infants averaged $30.3 \mathrm{~mm} \mathrm{Hg}$ and exceeded that of the normal adult. At this age the red cell 2,3-DPG was also considerably elevated while the fetal hemoglobin concentration had decreased to that of the normal adult.

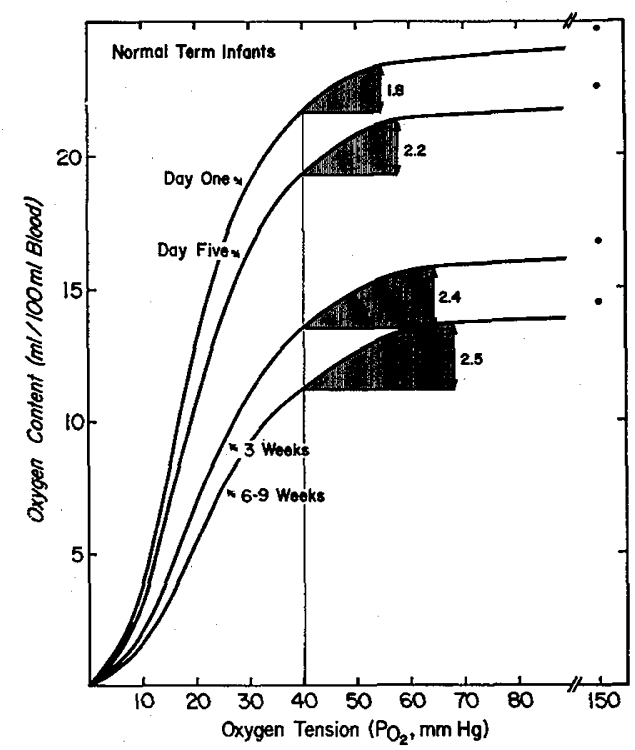

Figs. 3 and 4. Oxygen equilibrium curves of blood from term infants at different postnatal ages. Double arrows represent the oxygen-unloading capacity between a given "arterial" and "venous" $\mathrm{Po}_{2}$. Points corresponding to $150 \mathrm{~mm} \mathrm{Hg}$ on the abscissa are the $\mathrm{O}_{2}$ capacities; each curve represents the mean value of the infants studied in each age group.

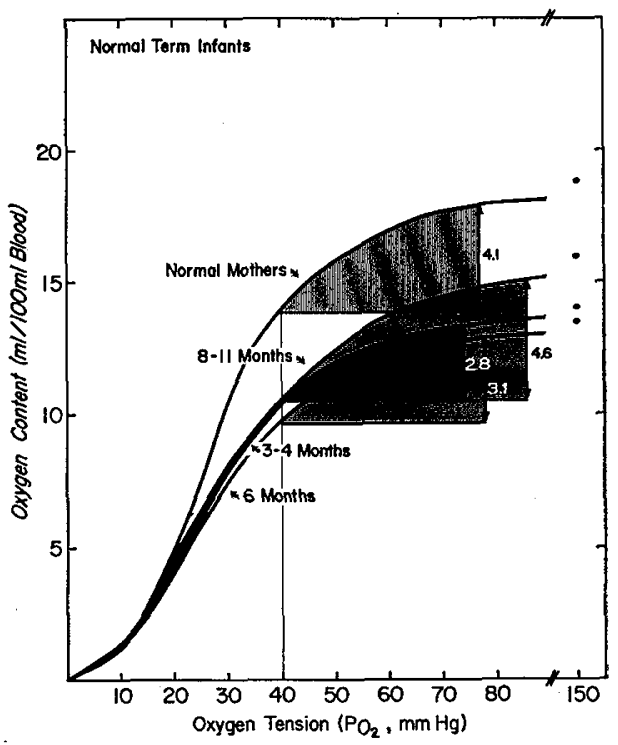

Fig. 4. 
The functioning DPG fraction that initially was $1246 \pm 570 \mathrm{~m} \mu \mathrm{moles} / \mathrm{ml} \mathrm{RBC}$ increased to $1516 \pm 495$ by day 5 and reached the normal adult value of 4000-5000 $\mathrm{m}_{\mu}$ moles/ml RBC by 4-6 months of age. When the value for $P_{50}$ was related to the red cell DPG alone or the adult hemoglobin concentration alone, no significant correlation was observed. When the value for $P_{50}$ was related to the functioning DPG fraction (Fig. 2), the correlation coefficient was 0.876
$(P<0.001)$. The unloading capacities shown in Figures 3 and 4 increased from day 1 of life to reach adult levels at 6 months.

\section{Normal Premature Babies}

The results of the studies obtained from premature infants are grouped according to their birth weight (Table II).

Group I was comprised of infants of less than $1000 \mathrm{~g}$;

Table II. Oxygen transport in premature infants

\begin{tabular}{|c|c|c|c|c|c|c|c|c|}
\hline Age & $\begin{array}{l}\text { Total Hb, } \\
\text { g/100 ml blood }\end{array}$ & Hct, \% & $\mathrm{MCHC}, \%$ & $\begin{array}{l}\mathrm{O}_{2} \text { capacity } \\
\text { ml/100 ml } \\
\text { blood }\end{array}$ & $\begin{array}{c}\mathrm{P}_{50} \text { at } \mathrm{pH} \\
7.40, \\
\mathrm{~mm} \mathrm{Hg}\end{array}$ & $\begin{array}{l}\text { 2,3-DPG, } \\
\mathrm{m} \mu \mathrm{moles} / \mathrm{ml} \\
\mathrm{RBC}\end{array}$ & $\begin{array}{l}\text { Fetal } \mathrm{Hb} \\
\text { \% of } \\
\text { total }\end{array}$ & $\begin{array}{c}\text { FFDPG, } 1 \\
\text { m } \mu \mathrm{moles} / \mathrm{ml} \\
\text { RBC }\end{array}$ \\
\hline \multicolumn{9}{|l|}{ Group I $(<1000 \mathrm{~g})^{2}$} \\
\hline 2 weeks & 17.2 & 47.0 & 36.6 & 23.9 & 18.0 & 6255 & 83.0 & 1002 \\
\hline 4 weeks & 8.5 & 26.0 & 32.7 & 11.8 & 15.0 & 3923 & 81.0 & 761 \\
\hline 9 weeks & 7.2 & 22.0 & 32.7 & 10.0 & 15.0 & 4636 & 87.1 & 974 \\
\hline 11 weeks & 7.7 & 22.5 & 34.2 & 10.7 & 17.0 & 5867 & 78.0 & 1290 \\
\hline \multicolumn{9}{|l|}{$\begin{array}{l}\text { Group II (1001- } \\
\quad 1,500 \mathrm{~g})\end{array}$} \\
\hline \multirow[t]{2}{*}{$1-2$ days } & 15.1 & 45.7 & 33.0 & 21.0 & 18.0 & 4124 & 86.6 & 580 \\
\hline & $\pm 1.3^{3}$ & \pm 3.7 & \pm 0.7 & \pm 1.8 & \pm 1.7 & \pm 1562 & \pm 3.1 & \pm 287 \\
\hline \multirow[t]{2}{*}{ 5-8 days } & 13.4 & 41.4 & 33.5 & 18.7 & 18.9 & 4501 & 84.4 & 903 \\
\hline & \pm 1.1 & \pm 3.2 & \pm 2.9 & \pm 1.5 & \pm 3.0 & \pm 1919 & \pm 3.8 & \pm 689 \\
\hline \multirow[t]{2}{*}{$2-3$ weeks } & 12.6 & 33.6 & 34.2 & 15.9 & 21.2 & 5721 & 83.3 & 1119 \\
\hline & \pm 3.1 & \pm 6.0 & \pm 1.1 & \pm 3.1 & \pm 1.9 & \pm 1375 & \pm 5.1 & \pm 557 \\
\hline \multirow[t]{2}{*}{$4-5$ weeks } & 8.8 & 25.3 & 34.9 & 12.3 & 20.5 & 6095 & 85.2 & 931 \\
\hline & \pm 0.9 & \pm 1.8 & \pm 1.7 & \pm 1.3 & \pm 1.7 & \pm 2081 & \pm 2.3 & \pm 456 \\
\hline \multirow[t]{2}{*}{$6-9$ weeks } & 9.1 & 24.5 & 35.1 & 11.8 & 23.4 & 8734 & 77.2 & 1995 \\
\hline & \pm 1.7 & \pm 5.8 & \pm 2.2 & \pm 2.4 & \pm 1.1 & \pm 1854 & \pm 1.9 & \pm 480 \\
\hline $9-10$ weeks $^{4}$ & 8.2 & 24.0 & 34.0 & 11.1 & 24.0 & 9000 & 77.0 & 2070 \\
\hline \multicolumn{9}{|l|}{$\begin{array}{l}\text { Group III (1501- } \\
\quad 2000 \mathrm{~g})\end{array}$} \\
\hline \multirow[t]{2}{*}{$1-2$ days } & 16.1 & 47.8 & 33.7 & 22.4 & 19.3 & 4475 & 87.2 & 703 \\
\hline & \pm 0.9 & \pm 1.9 & \pm 1.9 & \pm 1.2 & \pm 0.9 & \pm 1174 & \pm 3.6 & \pm 331 \\
\hline \multirow[t]{2}{*}{$5-8$ days } & 16.8 & 48.5 & 34.7 & 25.3 & 19.8 & 5489 & 79.4 & 1056 \\
\hline & \pm 3.3 & \pm 10.0 & \pm 0.5 & \pm 4.7 & \pm 1.3 & \pm 1428 & \pm 5.0 & \pm 590 \\
\hline \multirow[t]{2}{*}{$2-3$ weeks } & 13.6 & 40.4 & 34.4 & 18.8 & 21.3 & 6002 & 80.6 & 1184 \\
\hline & \pm 3.0 & \pm 9.8 & \pm 1.5 & \pm 4.0 & \pm 1.8 & \pm 998 & \pm 5.8 & \pm 329 \\
\hline \multirow[t]{2}{*}{ 4-5 weeks } & 11.2 & 31.9 & 35.5 & 15.5 & 20.8 & 5841 & 75.8 & 1569 \\
\hline & \pm 2.8 & \pm 9.9 & \pm 2.2 & \pm 3.8 & \pm 1.6 & \pm 839 & \pm 7.8 & \pm 577 \\
\hline \multirow[t]{2}{*}{$6-9$ weeks } & 8.0 & 22.1 & 35.9 & 11.1 & 24.0 & 7290 & 67.5 & 2457 \\
\hline & \pm 0.7 & \pm 1.7 & \pm 0.7 & \pm 1.0 & \pm 0.9 & \pm 634 & \pm 6.2 & \pm 575 \\
\hline \multicolumn{9}{|l|}{$\begin{array}{l}\text { Group IV (200I- } \\
2500 \mathrm{~g})\end{array}$} \\
\hline \multirow[t]{2}{*}{ 1-2 days } & 15.9 & 46.2 & 35.8 & 21.9 & 20.2 & 5306 & 76.8 & 1258 \\
\hline & \pm 0.9 & \pm 5.8 & \pm 1.9 & \pm 1.5 & \pm 1.6 & \pm 1075 & \pm 5.4 & \pm 392 \\
\hline \multirow[t]{2}{*}{$5-8$ days } & 15.6 & 47.0 & 34.2 & 21.5 & 21.3 & 6417 & 77.7 & 1457 \\
\hline & \pm 1.7 & \pm 5.0 & \pm 1.1 & \pm 2.4 & \pm 3.3 & \pm 1527 & \pm 6.3 & \pm 603 \\
\hline \multirow[t]{2}{*}{$2-3$ weeks } & 12.3 & 35.1 & 34.9 & 17.1 & 22.0 & 7145 & 76.9 & 1666 \\
\hline & \pm 1.1 & \pm 3.2 & \pm 0.5 & \pm 1.5 & \pm 1.3 & \pm 1737 & \pm 4.7 & \pm 472 \\
\hline $6-9$ weeks ${ }^{4}$ & 14.0 & 44.0 & 34.0 & 19.5 & 25.5 & 7100 & 43.0 & . 3212 \\
\hline
\end{tabular}

1 Functioning fraction of 2,3-diphosphoglycerate.

2 Only one patient.

${ }^{3}$ Values are given as mean $\pm \mathrm{sD}$.

4 Less than five infants. 


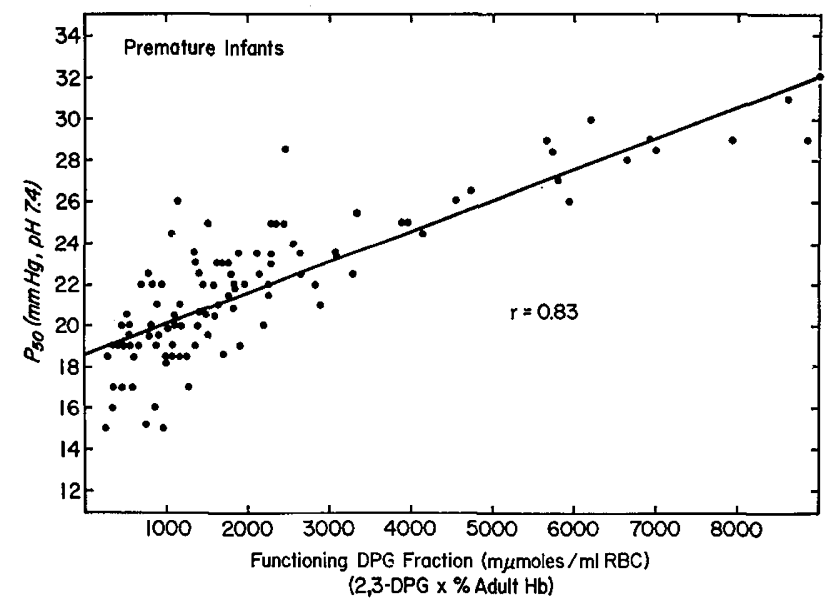

Fig. 5. The $P_{50}$ and functioning DPG fraction of all premature infants at different postnatal ages.

group II, 1001-1500 g; group III, 1501-2000 g; and group $I V$, infants weighing 2001-2460 g. Where applicable, results were expressed as mean \pm 1 sD.

In general the smaller infants had lower red cell DPG, lower $\mathrm{P}_{50}$, and higher fetal hemoglobin concentrations. During the first several weeks of life these small infants had functional DPG fractions that were significantly lower than those of the term infants.

Group $I$. Only three infants were admitted to the nursery during the study period, of whom only one survived beyond 1 week of age. The results are given in Table II.

Group II. The mean $\mathbf{P}_{50}$ during the first 2 days of life was $18 \mathrm{~mm} \mathrm{Hg}$, rose to 18.9 at 1 week, and was 21.0 $\mathrm{mm} \mathrm{Hg}$ for the following 6 weeks after which time there was a significant increase to $23.4 \mathrm{~mm} \mathrm{Hg}$. Red cell 2,3-DPG was $4124 \mathrm{~m}_{\mu}$ moles/ml RBG during the first 2 days of life and gradually increased to 4501 at 1 week, to 5721 at 3 weeks, 6095 at 4-5 weeks, and 8734 $\mathrm{m} \mu \mathrm{moles} / \mathrm{ml} \mathrm{RBC}$ at 6-9 weeks. Fetal hemoglobin remained unchanged for the first 6 weeks at $84.5 \pm$ $3.0 \%$. The functioning DPG fraction, however, steadily increased from $580 \mathrm{~m} \mu$ moles/ml RBC during week 1 to $2000 \mathrm{~m} \mu$ moles $/ \mathrm{ml} \mathrm{RBC}$ by $6-9$ weeks of age.

Group III. The mean $\mathrm{P}_{50}$ was $19.3 \mathrm{~mm} \mathrm{Hg}$ during the first 2 days of life and rose to 19.8 at the end of week 1 and to $21.3 \mathrm{~mm} \mathrm{Hg}$ between weeks 2 and 3; by 6-9 weeks the mean $P_{50}$ was $23.0 \mathrm{~mm} \mathrm{Hg}$. Red cell 2,3-DPG initially was $4475 \mathrm{~m} \mu$ moles $/ \mathrm{ml} \mathrm{RBC}$ and rose to 5489 by the end of week 1 and to 6002 by $2-3$ weeks; at 6-9 weeks the red cell 2,3-DPG was $7290 \mathrm{~m} \mu$ moles $/ \mathrm{ml}$ RBC. Fetal hemoglobin slowly decreased from $87.2 \pm$ $3.6 \%$ at birth to $67.5 \%$ by $6-9$ weeks of age. Func- tional DPG fraction increased from 703 at birth to $2457 \mathrm{~m} \mu \mathrm{moles} / \mathrm{ml} \mathrm{RBC}$ at $6-9$ weeks of age.

Group $I V$. The mean $\mathrm{P}_{50}$ was $20.2 \mathrm{~mm} \mathrm{Hg}$ at 2 days of age and rose to 21.3 at week $I$ and to $22.0 \mathrm{~mm} \mathrm{Hg}$ at 2-3 weeks of age. Red cell 2,3-DPG was 5306 $\mathrm{m} \mu$ moles $/ \mathrm{ml} \mathrm{RBC}$ at 2 days and rose to 6417 at week 1 , and $7145 \mathrm{~m} \mu \mathrm{moles} / \mathrm{ml} \mathrm{RBC}$ at 2-3 weeks of age. Fetal hemoglobin remained relatively unchanged at $77.0 \%$ for the first 3 weeks of age. The functioning DPG fraction increased from 1250 to $1670 \mathrm{~m} \mu$ moles $/ \mathrm{ml}$ RBC during the first 3 weeks of life.

For the entire group of premature infants the correlation coefficient between the $\mathrm{O}_{2}$ affinity and the functioning DPG fraction was $0.867(P<0.001$ (Fig. 5)). For all groups the mean oxygen unloading capacities are depicted in Figures 6, 7, and 8. All the premature infants had smaller unloading oxygen capacities initially than the term infants and did not catch up during the first 3 months of life.

\section{Infants with Respiratory Distress Syndrome}

The findings in 12 infants with the respiratory distress syndrome are presented in Table III and contrasted with those of normal premature and term infants. In this group of 12 infants the $P_{50}$, the red cell

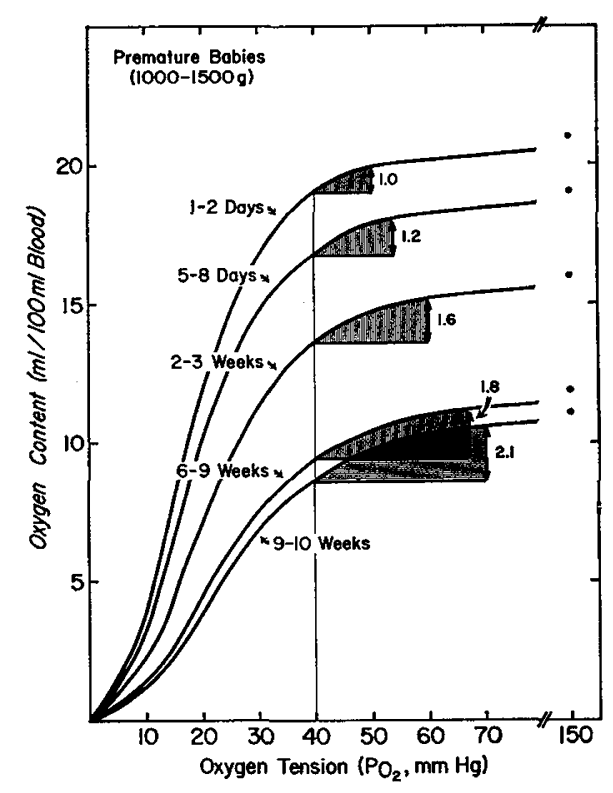

Figs. 6, 7, and 8. Oxygen equilibrium curves of blood from all weight groups of premature infants at different postnatal ages. Double arrows represent the oxygen-unloading capacity between a given "arterial" and "venous" $\mathrm{Po}_{2}$. Points corresponding to 150 $\mathrm{mm} \mathrm{Hg}$ on the abscissa are the $\mathrm{O}_{2}$ capacities; each curve represents the mean value of the infants studied in each age group. 


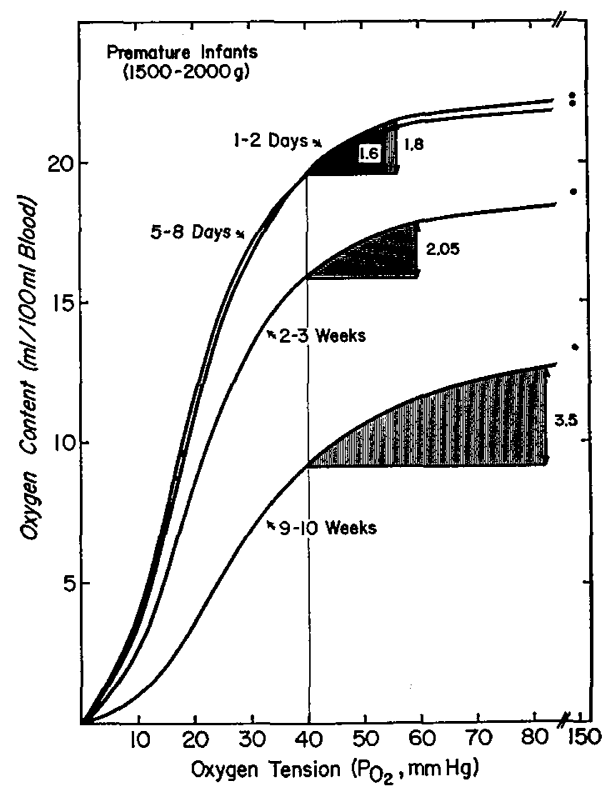

Fig. 7.

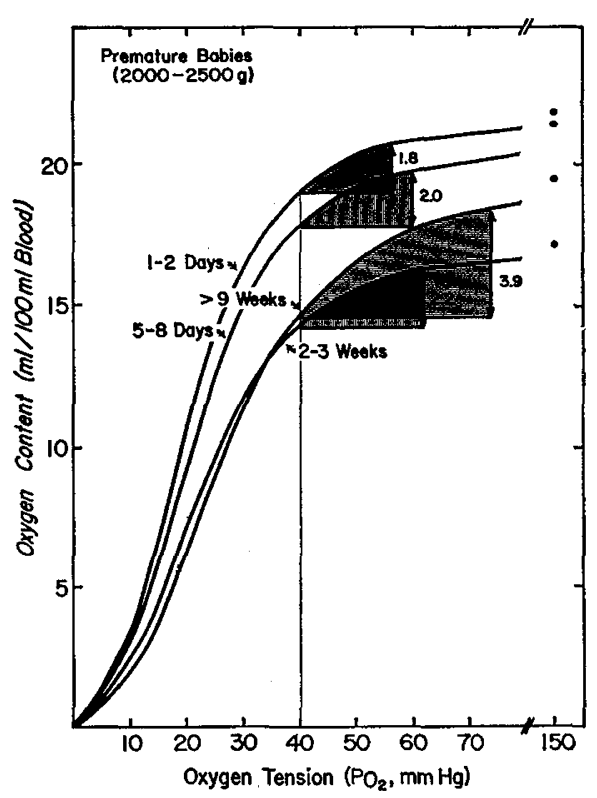

Fig. 8.

2,3-DPG, and the functioning fraction of DPG were all found to be significantly lower. The sequential changes in the $P_{50}$, the red cell 2,3-DPG, percentage fetal hemoglobin, and the functioning fraction of 2,3DPG, in four infants who received exchange transfusion are presented in Table IV. In these infants a marked increase in the $P_{50}$ was produced by the exchange transfusion. This was a consequence of a de- crease in the fetal hemoglobin concentration and an increase in the functioning fraction of 2, 3-PDG.

\section{Discussion}

These studies confirm previous observations that the term infant begins life with blood having an increased affinity for oxygen. During the first few months of life the oxygen-hemoglobin equilibrium curve gradually shifts to the right and (between 4 and 6 months of

Table III. Oxygen transport in infants with respiratory distress syndrome

\begin{tabular}{|c|c|c|c|c|c|}
\hline $\begin{array}{l}\text { Infant } \\
\text { group }\end{array}$ & $\begin{array}{l}\text { Birth } \\
\text { wt, g }\end{array}$ & $\begin{array}{c}\mathrm{P}_{60} \text { at } \\
\mathrm{pH} \mathrm{7.40,} \\
\mathrm{mm} \mathrm{Hg}\end{array}$ & $\begin{array}{c}\text { 2,3-DPG, } \\
\text { mpmoles } / \mathrm{ml} \\
\mathrm{RBC}\end{array}$ & $\begin{array}{c}\text { Fetal Hb, } \\
\text { \% of } \\
\text { total }\end{array}$ & $\begin{array}{c}\text { FFDPG } \\
\text { mumoles } \\
\text { RBC }\end{array}$ \\
\hline \multirow[t]{2}{*}{ Term } & 3100 & 19.4 & 5433 & 77.0 & 1246 \\
\hline & $\pm 520^{2}$ & \pm 1.8 & \pm 1041 & \pm 7.3 & \pm 570 \\
\hline \multirow[t]{2}{*}{ Prematures } & 1500 & 18.6 & 4320 & 86.9 & 640 \\
\hline & \pm 410 & \pm 1.6 & \pm 1280 & \pm 3.2 & \pm 300 \\
\hline \multirow{2}{*}{$\begin{array}{l}\text { Respiratory } \\
\text { distress } \\
\text { syndrome }\end{array}$} & 1490 & 16.5 & 2640 & 87.3 & 343 \\
\hline & \pm 240 & \pm .8 & \pm 575 & \pm 2.8 & \pm 187 \\
\hline
\end{tabular}

${ }^{1}$ Functioning fraction of 2,3-diphosphoglycerate.

${ }^{2}$ All values are given as mean $\pm 1 \mathrm{sD}$.

Table IV. Sequential changes in oxygen affinity following exchange transfusion of infants with respiratory distress syndrome

\begin{tabular}{|c|c|c|c|c|c|}
\hline Infant & $\begin{array}{l}\text { Birth } \\
\text { wt, } g\end{array}$ & $\begin{array}{l}\mathrm{P}_{50} \text { at } \\
\mathrm{pH} 7.40 \\
\mathrm{~mm} \mathrm{Hg}\end{array}$ & $\begin{array}{l}\text { 2,3-DPG, } \\
\text { m } \mu \text { moles } / \\
\text { ml } \\
\text { RBC }\end{array}$ & $\begin{array}{l}\text { Fetal } \\
\text { Hb, \% } \\
\text { of total }\end{array}$ & $\begin{array}{c}\text { FFDPG } \\
\text { mumoles } \\
\text { ml } \\
\text { RBC }\end{array}$ \\
\hline \multicolumn{6}{|c|}{$\begin{array}{l}\text { Before exchange } \\
\text { transfusion }\end{array}$} \\
\hline$C^{2}$ & 1300 & 17.0 & 2900 & 83.5 & 478 \\
\hline$S$ & 1100 & 19.0 & 4137 & 88.6 & 472 \\
\hline$W$ & 1790 & 19.0 & 4000 & 82.3 & 669 \\
\hline$J^{3}$ & 2381 & 19.0 & 3467 & 87.2 & 440 \\
\hline \multicolumn{6}{|c|}{$\begin{array}{l}\text { One day after ex- } \\
\text { change transfu- } \\
\text { sion }\end{array}$} \\
\hline C & & 21.0 & 3020 & 63.1 & 812 \\
\hline$S$ & & 23.5 & 3047 & 4.1 & 2922 \\
\hline$W$ & & 23.5 & 7535 & 64.8 & 2652 \\
\hline$J$ & & 24.5 & 4263 & 4.0 & 4118 \\
\hline \multicolumn{6}{|c|}{$\begin{array}{l}\text { One week after ex- } \\
\text { change transfu- } \\
\text { sion }\end{array}$} \\
\hline C & & 22.5 & 4435 & 38.9 & 2700 \\
\hline$S$ & & 26.0 & 4791 & 4.1 & 4595 \\
\hline$W$ & & 25.0 & 7902 & 60.9 & 3090 \\
\hline$J$ & & 29.0 & 7221 & 3.9 & 6939 \\
\hline
\end{tabular}

1 Functioning fraction of 2,3-diphosphoglycerate.

${ }^{2}$ Simple transfusion of $30 \mathrm{ml}$ fresh heparinized blood.

${ }^{3}$ Infant of a diabetic mother, 36 weeks gestation, ventilated by intermittent positive pressure respiration. 
age) becomes similar to that of the normal adult. Sequential studies performed in infants born prematurely reveal that this shift in the oxygen-hemoglobin equilibrium curve is far more gradual for the first 3 months of life, in comparison to the term infant. Adult values are not achieved in group $I$ and $I I$ infants until late in the 1st half-year of life.

This study, like previous studies $[4,8]$, failed to demonstrate a precise correlation between the decrease in the oxygen affinity of the neonate's blood and the progressive decline in the concentration of fetal hemoglobin $(r=0.410)$. The observation that the $P_{50}$ in the term infant actually increases from a mean of 19.4 to 20.6 during week 1 of life while fetal hemoglobin concentration remains unchanged clearly suggests the influence of other factors.

During this lst week of life the level of red cell 2,3DPG rises sharply [21] and then returns to the initial birth level by weeks $2-3$ and remains unchanged for the next 6 months. The same pattern was also observed in newborn lambs [5].

In adults the decreased oxygen affinity of hemoglobin in the presence of normal temperature and hydrogen ion concentration seems to be controlled by the concentration of the red cell 2,3-DPG. Increased 2,3DPG levels and a displacement of the oxygen equilibrium curve to the right have been documented in numerous clinical conditions $[14,18,24,26,27]$. In contrast, when the data from both the term and premature infants were evaluated, it was observed that the position of the oxygen-hemoglobin equilibrium curve, as reflected by the $P_{50}$, was not directly related to the total red cell 2,3-DPG.

Thus the change in $P_{50}$ in these infants correlated neither with the change in red cell DPG content alone nor with the decline in fetal hemoglobin alone. Instead, the progressive decrease in oxygen affinity during the first 6 months of life correlated significantly $\langle r=0.876, P<0.001)$ with the functioning DPG fraction. The term "functioning fraction" is not intended to imply that a compartmentalized portion of the red cell's 2,3-DPG is in combination with the hemoglobin but instead is introduced to underscore the fact that both 2,3-DPG and adult hemoglobin act in concert to determine the oxygen affinity of the cell.

This relation serves to explain why during week 1 of life infants with similar concentrations of fetal and adult hemoglobin may have marked differencés in their $\mathrm{P}_{50} \mathrm{~s}$. Infants with more adult hemoglobin but less DPG may have a $P_{50}$ similar to that of an infant with a high red cell DPG but increased quantities of fetal hemoglobin.

The oxygen-carrying capacity of the blood decreases during the first $3-4$ months of life because of the progressive fall in the total hemoglobin concentration. Despite this fall in the oxygen-carrying capacity the oxygen-unloading capacity is enhanced as a result of the gradual shift to the right of the oxygen-hemoglobin equilibrium curve. In Figures 2 and 3 sequential increases in the ability of blood to deliver oxygen are illustrated. At a mixed venous oxygen tension of 40 $\mathrm{mm} \mathrm{Hg}$, arbitrarily selected as the normal venous oxygen tension at rest, the 3-month-old infant is delivering more oxygen to his tissues than the newborn infant despite the fact that his hemoglobin has fallen from $17.0 \mathrm{~g} / 100 \mathrm{ml}$ to approximately $10.5 \mathrm{~g} / 100 \mathrm{ml}$. The increase in the oxygen-unloading capacity also correlates with the increase in the functioning DPG fraction.

It would appear that exposure to the normal atmospheric environment is not the stimulus for the decrease in fetal hemoglobin concentration. The level of fetal hemoglobin persists in the infants born prematurely for much longer periods of time than is observed in those infants born at term. The maturational factors responsible for this "switch" from fetal to adult hemoglobin synthesis remain unknown.

At about 3 months of age it has been shown that erythropoietin secretion increases and can be detected in the urine [25]. The increase in erythropoietin secretion at this age has been attributed to the anemia that has developed with its resultant hypoxemia, Our findings would suggest that anemia per se is not responsible; but at this time increased oxygen demands must be present which then result in increased oxygen utilization, increased oxygen extraction, and a resultant decrease in tissue oxygen tension. This decrease in tissue oxygen tension would then serve as the stimulus for erythropoietin and not merely the fall from 17 to $10.5 \mathrm{~g} / 100 \mathrm{ml}$ in the hemoglobin concentration.

The effects of exchange transfusion or simple transfusions of adult blood clearly illustrate (Fig. 9) the effects of increasing the adult hemoglobin concentration and the functioning DPG fraction on tissue oxygen delivery. Immediately after transfusion the functioning DPG fraction increased, the $\mathrm{P}_{50}$ shifted to the right, and the unloading capacity of the blood for oxygen increased. By the following day the oxygen affinity for hemoglobin and the unloading capacity, in most cases, compared; with those of normal adults. At this point the functioning DPG fraction had reached 
the level of the adult's normal red cell DPG total content.

In sick infants these procedures facilitate oxygen release at higher tissue oxygen tensions. Without this shift to the right, the infant, in times of need, would be forced to drop his tissue oxygen tension or markedly increase his cardiac output in order to extract increased amounts of oxygen. The newborn infant has a limited capacity to increase his cardiac rate. A significant fall in the oxygen tension would result in encroachment upon the ill defined level of "critical oxygen tension." When central venous oxygen tensions drop below this level, oxygen diffusion exchange in the periphery may be impaired because of the narrowed gradient between vessel and cell.

The infants with respiratory distress appeared to have $\mathbf{P}_{50}$ s that were lower than those of healthy infants $[16,19]$ of similar gestational age and birth weight. This appears to be primarily a result of a decrease in red cell DPG concentration. It is this type of infant who may benefit from exchange transfusion with fresh adult blood provided that arterial oxygen tension is also raised to $50-60 \mathrm{~mm} \mathrm{Hg}$. The potentially fatal case of baby J, an infant with severe respiratory distress, illustrates this point. This infant had a progressive fall in his arterial $\mathrm{Po}_{2}$ to $16 \mathrm{~mm} \mathrm{Hg}$ at $12 \mathrm{hr}$ of age and was moribund. In this infant intubation and assisted ventilation were instituted, which raised the arterial $\mathrm{Po}_{2}$ to $60 \mathrm{~mm} \mathrm{Hg}$. Then an exchange transfusion was performed. Infants with this severe degree of hypoxemia associated with the respiratory distress syndrome do not survive, even with assisted ventilation (13). Baby $J$ did survive the neonatal period, and his course is illustrated in Figure 9.

To date, most studies of the respiratory distress syndrome in the newborn have focused on arterial oxygenation, a variable of obvious importance, and little attention has been given to an equally important physiologic variable, that of oxygen release. Replacement of blood containing primarily fetal hemoglobin with that containing adult hemoglobin does not hinder arterial oxygenation in the extrauterine environment, providing the arterial oxygen tension does not fall below $50-60 \mathrm{~mm} \mathrm{Hg}$. Oxygen unloading, however, is facilitated by this procedure by decreasing the affinity of hemoglobin for oxygen.

Fresh adult blood must be used if the procedure is to be helpful because the $\mathrm{P}_{50}$ of adult blood falls rapidly with storage (38).

It will be necessary to measure both arterial and

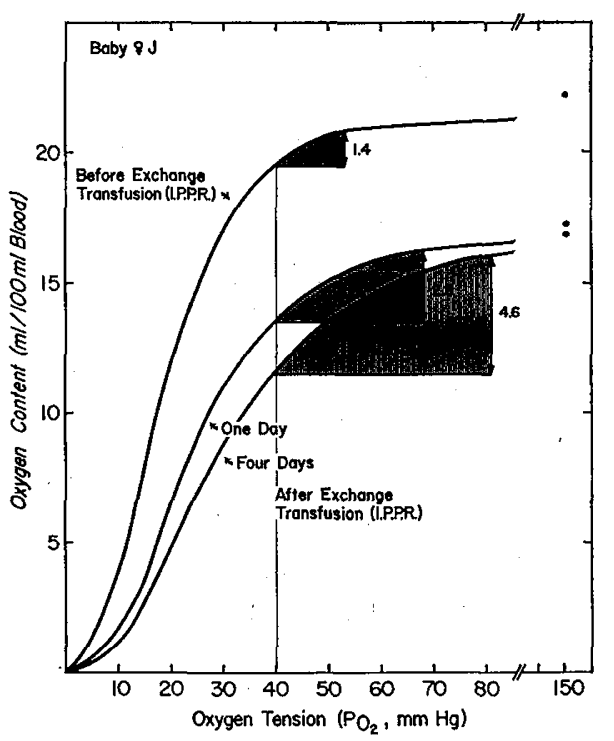

Fig. 9. The sequential oxygen equilibrium curves of the blood of an infant with severe respiratory distress syndrome treated with exchange transfusion and intermittent positive pressure respiration. Double arrows represent the oxygen-unloading capacity between a given "arterial" and "venous" $\mathrm{Po}_{2}$. Points corresponding to $150 \mathrm{~mm} \mathrm{Hg}$ on the abscissa are the $\mathrm{O}_{2}$ capacities. In this infant the oxygen delivery increased from 1.4 to $4.6 \mathrm{ml}$ during the course of 1 week.

central venous oxygen tension in these infants both before and after exchange transfusion to confirm these theoretical calculations.

It is of considerable interest that the incidence of the respiratory distress syndrome appears decreased in those infants receiving intrauterine exchange transfusions of adult blood [39]. Obviously, other factors may be operative, but the role of adult hemoglobin must be critically examined.

\section{Summary}

Sequential studies of the $P_{50}$, fetal hemoglobin, and red cell DPG concentrations were performed in 48 term and 56 premature infants. In term infants the $P_{50}$ averaged $19.4 \mathrm{~mm} \mathrm{Hg}$ on day $1 ; 20.6$ on day 5; 26.6 at 3-4 months, and 28.0 at 6 months (normal adult 27.0 $\pm 1.1 \mathrm{~mm} \mathrm{Hg}$ ). The initial $P_{50}$ of the premature infants was lower, and its change during the first 3 months of age was more gradual. In all babies the $P_{50}$ did not correlate precisely with the percentage fetal hemoglobin alone or the DPG alone but correlated significantly with the product of the red cell DPG content times the percentage adult hemoglobin ("functioning DPG fraction"). Calculations indicated that 
the term infant at 3 months of age with a hemoglobin of $11.0 \mathrm{~g} / 100 \mathrm{ml}$ was delivering more oxygen to his tissues at a mean venous $\mathrm{PO}_{2}$ of $40 \mathrm{~mm} \mathrm{Hg}$ than the newborn with a hemoglobin of $17.0 \mathrm{~g} / 100 \mathrm{ml}$ blood. Sick infants were found to have lower $\mathrm{P}_{50} \mathrm{~s}$ and DPG levels than normal infants. Infants given either simple or exchange transfusions of fresh adult blood showed an increased functioning DPG fraction, a shift of the oxygen equilibrium curve to the right, and an oxygenunloading capacity that reached levels of a 6-monthold infant. It is suggested that exchange transfusion with fresh adult blood may be beneficial to these sick infants by raising their functioning DPG fraction and thus increasing their oxygen delivery to tissues at higher venous oxygen tensions.

\section{References and Notes}

1. Allen, D. W., Wyman, T., and Smith, C. A.: The oxygen equilibrium of fetal and adult human hemoglobin. J. Biol. Chem., 203: 84 (1953).

2. Anselmino, K. T., AND Hoffman, F.: Die Ursachen des Icterus Neonatorum. Arch. Gynäk, 143: 477 (1930).

3. Avery, M. E.: In: The Lung and Its Disorders in the Newborn Infant (Saunders, Philadelphia, 1968).

4. Bartels, H.: Prenatal Respiration (North-Holland Publishing, Amsterdam, 1970).

5. Batraglia, F. C., McGaughex, H., Makowski, E. L., And Meschia, J. G.: Postnatal changes in $\mathrm{O}_{2}$ affinity of sheep red cells; a dual role of diphosphoglyceric acid. Amer. J. Physiol. (in press).

6. Bauer, C., Ludwig, L., ANd Ludwig, M.: Different effect of 2,3-diphosphoglycerate and adenosine triphosphate on the oxygen affinity of human adult and foetal hemoglobin. Life Sci., 7: 1339 (1968).

7. Bauer, C., Ludwig, M., Ludwig, I., ANd Bartels, H.: Factors governing the oxygen affinity of human adult and foetal blood. Resp. Physiol. 7: 271 (1969).

8. Beer, R., Dolt, E., and Wenner, G.: Die Verschiebung der Sauerstoffdissoziationskurve des Blutes von Säuglingen wahrend der ersten Lebensmonate. Pflügers Arch. Ges. Physiol., 265: 526 (1958).

9. BENESCH, R., AND BenEsch, R. E.: The effect of organic phosphates from the human erythrocyte on the allosteric properties of hemoglobin. Biochem. Biophys. Res. Commun., 26: 162 (1967).

10. Beutler, E., And Wood, L.: The in vivo regeneration of red cell 2,3-disphosphoglyceric acid (DPG) after transfusion of stored blood. J. Lab. Clin. Med., 74: 300 (1969).

11. Chanutin, A., And Curnish, R. R.: Effect of organic and inorganic phosphates on the oxygen equilibrium of human erythrocytes. Arch. Biochem. Biophys., 96: 121 (1967).

12. Crowley, J., Ways, P., and Jones, T. W.: Human fetal erythrocytes and plasma lipids. J. Clin. Invest., 44: 989 (1965).

13. Delivoria-Papadopoulos, M., Levison, H., and SwYer, P. R.: Intermittent positive pressure respiration as a treatment in severe respiratory distress syndrome. Arch. Dis. Childhood, 40: 474 (1965).
14. Delivoria-Papadopoulos, M., Oski, F. A., and Gottlieb, A. J.: Oxygen-Hemoglobin dissociation curves: Effect of inherited enzyme defects of the red cells. Science, 165: 601 (1969).

15. De Verdier, C. H., and Garby, L. Low binding of 2,3-diphosphoglycerate to haemoglobin F. Scand. J. Clin. Lab. Invest., 23: 149 (1969).

16. Duc, G. V., AND ENGEL, K.: Hemoglobin-oxygen affinity and erythrocyte 2,3-diphosphoglycerate (DPG) content in hyaline membrane disease (HMD) and cardiac malformations (CM). Society for Pediatric Research Program and Abstracts, 40th Annual Meeting, p. 79, 1970.

17. Eastman, N. J., Geiling, E. M. K., and Delawder, A. M.: Foetal blood studies. VI. The oxygen and carbon dioxide dissociation curves of foetal blood. Bull. Johns Hopkins Hosp., 53: 246 (1933).

18. EATON, J. W., AND BREWER, G. J.: The relationship between red cell 2,3-diphosphoglycerate and levels of hemogiobin in the human. Proc. Nat. Acad. Sci. U. S. A., 61: 756 (1968).

19. Frori, R. M., Eisenstein, E. B., Boyer, M. Y., Cherry, R. B., and Nelson, N. M.: Effect of admixed adult red cells on the position of the $\mathrm{O}_{2}$ dissociation curve of fetal blood. Society for Pediatric Research Program and Abstracts, 40th Annual Meeting, p. 223, 1970.

20. Haselyorst, G., AND Stromberger, K.: Über den Gasgehalt des Nabelschnurblutes vor and nach der Geburt des Kindes und über den Gasaustausch in der Plazenta. Z. Geburtsh Gynek., 10: 49 (1931).

21. HJELM, M.: The content of 2,3-diphosphoglycerate and some other phosphocompounds in human erythrocytes during the neonatal period. Försvarsmedicin, 5: 195 (1969).

22. Hollan, S. R., Szelenyi, I. Y., Breuer, J. H., Medgyesi, G., AND SOTER, V. N.: Structural and functional differences between human foetal and adult erythrocytes. Haematologia, 409 (1967).

23. KRIMSKY, I.: D-2, 3-Diphosphoglycerate. In: H. U. Bergmeyer: Methods of Enzymatic Analysis, ed. 1, p. 238 (Academic Press, New York, 1963).

24. Lenfant, C., Torrance, T., English, E., Finch, C. A., Reynafarja, C., Ramos, J., and Flaura, J.: Effect of altitude on oxygen binding hemoglobin and on organic phosphate levels. J. Clin. Invest., 47: 2652 (1968).

25. Mann, D. L., Siter, M. D., Donati, R. M., and Gallagher, M. I.: Erythropoietic stimulating activity during the first ninety days of life. Proc. Soc. Exp. Biol. Med., 118: 212 (1965).

26. Miller, W. W., Delivoria-Papadopoulos, M. Miller, L. D., AND OsKI, F. A.: Oxygen releasing factor in hyperthyroidism. J. Amer. Med. Ass., 211: 37 (1970).

27. Miller, W. W., Delivoria-Papadopoulos, M., and Oski, F. A.: Increased oxygen-hemoglobin dissociation: An adaptive response to hypoxemia and heart failure controlled by red cell 2,3-diphosphoglycerate. Circ. Res. (in press).

28. NAHAS, G. G.: A simplified cuvette for the spectrophotometric measurement of hemoglobin and oxyhemoglobin. J. Appl. Physiol., 13: 147 (1958).

29. Nechtman, C. M., and Huisman, T. H. J.: Comparative studies of oxygen equilibria of human adult and cord blood red cell hemolysates and suspensions. Clin. Chim. Acta, 10: 165 (1964). 
30. Oski, F. A., Gottlieb, A. J., Mrller, W. W., ANd DelivoriaPapadopoulos, M.: The effect of deoxygenation of adult and fetal hemoglobin on the synthesis of red cell 2,3-diphosphoglycerate and its in vivo consequences. J. Clin. Invest., 49: $400(1970)$.

31. SCHröTer, W., and Von Heyden, H.: Kinetik des 2,3-diphosphoglyceratumsatzes in menschlichen Erythrocyten. Biochem. Z., 341: 387 (1965).

32. Schruefer, J. J. P., Heller, C. J., Battaglia, F. C., and HELLEGERS, A. E.: Independence of whole blood and haemoglobin solution oxygen dissociation curves from haemoglobin type. Nature, 186: 550 (1962).

33. Severinghaus, J. W.: Blood gas calculator. J. Appl. Physiol., 21: 1108 (1966)

34. Severinghaus, J. W., And Bradley, A. F.: Electrodes for blood $\mathrm{PCO}_{2}$ and $\mathrm{PO}_{2}$ determination. J. Appl. Physiol., 13: 515 (1958).

35. Singer, R. B., Chernoff, A. I., And Singer, L.: Studies on abnormal hemoglobins. I. Their demonstration in sickle cell anemia and other hemotologic disorders by means of alkali denaturation. Blood, 6: 413 (1951).

36. Singer, R. B., AND Hastings, A. B.: An improved clinical method for the estimation of disturbances of the acid-base balance of human blood. Medicine, 27: 223 (1948).

37. Tyuma, I., And Shimizu, K.: Different responses to organic phosphates of human fetal and adult hemoglobin. Arch. Biochem., 129: 404 (1969).
38. Valtis, D. J., And Kennedy, A. C.: Defective gas-transport function of stored red-blood cells. Lancet, $i$ : 119 (1954).

39. WEAST, R. C.: Molar volume. In: Handbook of Chemistry and Physics (Chemical Rubber Company, City, 1967).

40. Westin, B., Nyberg, R., Miller, J. A., AND Wedenberg, E.: Hypothermia and transfusion with oxygenated blood in the treatment of asphyxia neonotorum. Acta Paediat. Scand. suppl., 54: 139 (1962).

41. Informed consent was obtained in accordance with the provisions of the Declaration of Helsinki.

42. The authors wish to express their gratitude to Dr. Robert E. Forster, II, for valuable criticism and advice; to the nursing staff of the ward and premature nurseries and the outpatient pediatric clinic of the Hospital of the University of Pennsylvania for their cooperation in these studies; and to Patricia O'Neal for technical assistance.

43. Supported by Public Health Service Research Grants nos. 5 R01-HD1860-05 and HD01919 and Career Development Award no. 1-K04-HD4771.

44. Dr. N. P. Roncevic was a fellow of the American Association of University Women.

45. Requests for reprints should be addressed to: Dr. Maria Delivoria-Papadopoulos, University of Pennsylvania School of Medicine, Department of Physiology, Philadelphia, Pa. 19104 (USA).

46. Accepted for publication September 11, 1970. 